\title{
Processed Meats and Poultry Consumption Trends In North American Muslim Population
}

\author{
Syed A. Hussain, Ph.D. \\ Oak Brook, IL
}

DOI: http://dx.doi.org/10.5915/21-4-13510

\begin{abstract}
The American food supply is the most abundant and varied in the world and American Muslims have access to this tremendous bounty at an extremely low cost. The average American Muslim spends only $15 \%$ of disposable income on food. Two-thirds of this is spent on food consumed at home and about one-third on food away from home. The technological wonder we call the US food system is in flux. Before our very eyes, a new, modern global food system is being built on the remnants of traditional agriculture, food processing, food distribution, food marketing, and food consumption patterns. American Muslims are looking for excitement in their foods. This can be seen in the increased consumption of processed meats and poultry foods among first and second generation American Muslims. Processed meats and poultry products such as hot dogs, bologna, salami, pastrami, roast beef, and many others labeled "Halall" are appearing in specialty stores. For the first time in US history, the American Muslims' existence is being recognized in social, political, and economic sectors. This review will explore, for the first time, the current trends in consumption of processed meats and poultry by the North American Muslim population and its impact on the meat processing industry. The processed meats and poultry industry had better make the most of the present. The availability of these products will generate interest among Americans consumers from outside the Muslim minority.
\end{abstract}

Key words: American Muslims, "Halâl”" processed meats and poultry products, consumption trends.

\section{Introduction}

America's Muslim consumers comprise a market segment "Kabir, Kathir." The size and stature of this segment is growing faster than you can down a "Kuftah" and a "Shish Kabāb." The number of Muslims in the United States is growing three times faster than other minorties, with the exception of Hispanics. It can be safely estimated that by the year 2000 there will be 6 million Muslims in the United States, and they will represent $2.3 \%$ of the population. The

From the Department of Technical Services

Swift-Eckrich, Inc.

1919 Swift Drive

Oak Brook, IL 60522, USA

Reprint Requests: Syed A. Hussain, Ph.D.

Swift-Eckrich, Inc.

1919 Swift Drive

Oak Brook, IL 60522
Muslim community also has become more affluent as first and second generation residents attain higher educational levels and improve their professional status.

An average Muslim family's household income after taxes was estimated at $\$ 30,000$ annually by an earlier survey.' Also, those surveyed predicted that their income will increase by $7-12.5 \%$ annually.

The unique spending patterns and lifestyle characteristics of Muslims is likely to pique the interest of food and beverage marketers. An earlier survey ${ }^{1}$ had established that first generation Muslims are professionals and their average income is higher. Muslims spend more money per week on food than the rest of the population because their families tend to be larger. The average US Muslim household size is 3.5 persons, compared with the overall average of only 2.7 persons. $^{1}$

The geographical concentration of the US Muslim population also will help interested companies in 
Table 1. Annual Estimated Expenditures for Food Items by American Muslim Households in US Dollars

\begin{tabular}{|c|c|c|c|}
\hline & 1986 & 1987 & 1988 \\
\hline Rice & $\begin{array}{c}\$ 408 \\
(26.1)\end{array}$ & $\begin{array}{c}\$ 418 \\
(17.9)\end{array}$ & $\begin{array}{c}\$ 560 \\
(12.5)\end{array}$ \\
\hline Bread & $\begin{array}{c}45 \\
(2.9)\end{array}$ & $\begin{array}{r}58 \\
(2.5)\end{array}$ & $\begin{array}{l}129 \\
2.9)\end{array}$ \\
\hline Meat & $\begin{array}{c}279 \\
(17.9)\end{array}$ & $\begin{array}{c}447 \\
(19.1)\end{array}$ & $\begin{array}{c}903 \\
(20.2)\end{array}$ \\
\hline Fish & $\begin{array}{c}194 \\
(12.4)\end{array}$ & $\begin{array}{r}332 \\
(14.2)\end{array}$ & $\begin{array}{c}714 \\
(16.0)\end{array}$ \\
\hline Vegetables & $\begin{array}{c}287 \\
(18.4)\end{array}$ & $\begin{array}{c}448 \\
(19.1)\end{array}$ & $\begin{array}{r}805 \\
(18.0)\end{array}$ \\
\hline Milk products and eggs & $\begin{array}{c}182 \\
(11.7)\end{array}$ & $\begin{array}{c}247 \\
(10.6)\end{array}$ & $\begin{array}{r}396 \\
(8.9)\end{array}$ \\
\hline Prepared foods & $\begin{array}{r}67 \\
(4.3)\end{array}$ & $\begin{array}{c}120 \\
(5.1)\end{array}$ & $\begin{array}{r}277 \\
(6.2)\end{array}$ \\
\hline Processed meat & $\begin{array}{r}36 \\
(2.3)\end{array}$ & $\begin{array}{r}95 \\
(4.1)\end{array}$ & $\begin{array}{r}250 \\
(5.6)\end{array}$ \\
\hline Processed poultry & $\begin{array}{c}28 \\
(1.9)\end{array}$ & $\begin{array}{c}115 \\
(4.9)\end{array}$ & $\begin{array}{r}340 \\
(7.6)\end{array}$ \\
\hline Tea, coffee & $\begin{array}{r}15 \\
(0.9)\end{array}$ & $\begin{array}{r}29 \\
(1.2)\end{array}$ & $\begin{array}{r}52 \\
(1.2)\end{array}$ \\
\hline Fruit sodas & $\begin{array}{r}8 \\
(0.5)\end{array}$ & $\begin{array}{c}12 \\
(0.5)\end{array}$ & $\begin{array}{r}42 \\
(0.9)\end{array}$ \\
\hline Colas & $\begin{array}{c}13 \\
(0.8)\end{array}$ & $\begin{array}{r}15 \\
(0.6)\end{array}$ & $\begin{array}{r}13 \\
(0.3)\end{array}$ \\
\hline
\end{tabular}

Note: Figures in parentheses indicate percentage of total annual food item expenditures.

Source: Based on the researcher's survey during the two-year period in 1986-1988.

focusing their marketing efforts. The majority of Muslims live in California, New York, Miami and Chicago. With information like this available, a growing number of the nation's marketers will be thinking of Muslim foods.

Unlike Anglo-Americans in the general markets, Muslims will not buy products just because they are advertised and price-promoted. To win Muslim minds and stomachs takes person-to-person contact and neighborhood-by-neighborhood marketing. Companies interested in attracting Muslim consumers must earn brand loyalty by putting "Halāl" ingredients into the products they would like to market, and then only will they make any profit.

This study has been undertaken to explore the current trends in consumption of processed meats and poultry by the North American Muslim population, and its impact on the meat processing industry. This review will be helpful to the "Halāl" meat processors in serving the North American Muslim population and in accomodating their dietary and religious requirements.

\section{Materials and methods}

During a two year period in 1986-1988, a survey was conducted in five states. A call for volunteers to participate in the study was sent to different Muslim organizations. Of the 52 who volunteered, approximately half were selected, on the basis of their answers to a questionnaire, as meeting the criteria of good health, as having no extreme habits, and as practicing Muslim families. They were thoroughly informed verbally and in writing of the demands to be placed on them. Twenty-five were accepted into the study. A letter of consent was obtained from each of the subjects. The participants were paid nonmonetary incentives to participate in the study.

Subjects were given written instructions for keeping records of food puchases. Grocery records were kept on a specially designed purchase record form on a daily basis by each subject during the two year period in 1986-1988. Written instructions were also provided for use in describing the kind of food, the amount of purchases, and in recording the different fresh meats, including processed meats and poultry products used in mixed dishes. Each subject was instructed to keep a record of meal purchases at restaurants and any meals consumed outside their home. They were asked to record food brand names, method of food preparation, and recipes for mixed dishes. Records were returned to the researcher in a pre-paid envelope on a weekly basis. These were examined and if necessary a telephone interview was conducted to ensure completeness and accuracy of the record. Respondents' answers were categorized by age, household size, marital status, number of children, education level, employment status, income and country of birth. Although small, a nationally representative sample of American Muslim households was surveyed for the present study.

\section{Results}

Table 1 shows the annual estimated expenditures for food items by American Muslim household. Muslim processed meat consumption may be something of a surprise to those who have not closely studied the market. Although fresh Halāl meat is used generously in Muslim foods prepared in the United States, it is less common in the first and second generation Muslim population. The survey revealed that this is due to lack of guidance from the parents who had failed to teach their children the importance of Halāl.

Today's Muslim consumer is eating out more often and wants food that requires a minimum of preparation time. Several types of take-out foods such as hamburgers, pizza, fried, roasted or barbecued 
Table 2. Consumption of Muscle Foods; Muslim Household Consumption and Serving Frequency in a Two Year Period in 1986-1988.

\begin{tabular}{|c|c|c|c|}
\hline \multirow[b]{2}{*}{ Food } & \multicolumn{2}{|c|}{$\begin{array}{c}\% \text { of Total } \\
\text { Meat/Fish/Poultry Eating }\end{array}$} & \multirow{2}{*}{$\begin{array}{c}\text { Serving } \\
\text { Frequency }\end{array}$} \\
\hline & First Week & Second Week & \\
\hline Beef & 30 & 29 & 4.9 \\
\hline Lamb & 25 & 26 & 2.5 \\
\hline \multicolumn{4}{|l|}{ Processed } \\
\hline meat & 22 & 22 & 2.3 \\
\hline Poultry & 14 & 14 & 1.9 \\
\hline Fish/seafoo & 9 & 9 & 1.4 \\
\hline Total & 100 & 100 & \\
\hline
\end{tabular}

chicken, deli meats/cold cuts, and beef hot dogs are becoming popular among this generation.

Muslim purchasing patterns also are changing in the area of processed foods. Table 2 shows the consumption of muscle foods. Muslims tradionally have been more interested in buying fresh meats. The present survey shows that because of cultural influences and peer pressure at school and college, combined with convenience, more and more prepared foods including processed meats/poultry are being purchased by Muslim consumers.

The survey asked Muslim consumers what the top new products in supermarkets were. Even for 1986, "food products designed especially for microwave cooking"' were mentioned most often - by $89 \%$ of those surveyed. Tied for third place were "partially prepared foods that require less time to prepare at home" and "delicatessen or other carry-out food items," which were mentioned by $78 \%$ of those questioned. Convenience was identified by Muslim consumers as a major driving force behind purchases of new introductions in 1986 . It was the major driving force in 1987. Other factors influencing "hot" new foods in 1987 were health concerns ("if they don't interfere too much with taste'), taste, and value/quality relationship.

\section{Discussion}

Targeting Muslim consumers is a complex task, but it is not any more complex than targeting other market niches. However, competition for market share of prepared food items for Muslim consumers is not such a tough task. The good news is that, with the current sound economy and more Muslim households with dual wage earners, the demand for further processed, value-added foods such as processed meats/poultry will climb at an astounding rate.

It can cost a food company a substantial amount to coax stores located near concentrations of Muslims to stock a new product. However, as new software continues to become available allowing ac- curate and rapid grocery scanning data collection, supermarkets can scrutinize even more closely how well new products perform.

Another challenge faced by food manufacturers is increased competition from supermarkets themselves. As convenience foods play an even greater role in the lives of working women, single member households, and others who are looking to reduced food preparation time, supermarkets are responding by offering their own prepared foods. Many supermarket chains now have salad, soup or taco bars, along with delicatessen departments.

These in-store delicatessens and other prepared foods with Halal ingredients can be easily introduced into Muslim specialty stores, as there appears to be a fairly good demand for them among the Muslim population. This can be seen in the steady rise of processed meats and poultry consumption by the young Muslims at Islamic centers and schools across the United States and Canada.

Certain trends, such as convenience, will be around for a while. The US Department of Labor predicts that by $1990,76 \%$ of people between 25 and 44 years of age will be working outside the home. ${ }^{2}$ Young professionals and "empty nesters" are also prime candidates for convenience foods. Much of the future growth in the convenience food area will come from products offering improvements to what is currently available, at a price in line with what Muslim consumers perceive as good value.

By the end of 1987 , microwave ovens were in at least three-fourths of the homes in the United States. This is the latest estimate from the Association of Home Appliance Manufacturers (AHAM). ${ }^{3}$ In this survery almost half of those questioned use their microwave oven often for cooking frozen foods, and $38.7 \%$ reported using it often for cooking non-frozen foods.

This escalation of microwave oven use is having a dramatic effect on the prepared foods industry. American Muslims are spending hundreds of dollars on microwavable foods. Two things happened in the microwave specific category in Muslim households. Popcorn continued to dominate the category, but other seqments also began to pop.

There is room for microwave-specific Halāl foods. There is a growing demand for single-serving products. Muslim consumers want more products that work well in the microwave. The market has further been stimulated by the significant development of the ready meals market both in frozen and chilled form. Manufacturers have utilized ethnic recipes, including Muslim meal recipes, in their range of products. In general, the ready meal market is expanding rapidly and Muslim food recipes have added to this success.

To compete directly with fast food restaurants, microwave Halal foods such as a frozen line of Halal hamburgers, cheeseburgers, French fries and hash 
brown sticks in frozen and chilled forms can be particularly buoyant for the supermarkets and ethnic grocery multiples. The growth of this sector will originate from the number of Muslim families who begin shopping in the supermarkets and grocery multiples. This will encourage these multiples to stock a wide range of "Halal" products to cater to Muslim tastes, and, by displaying the products in a block, can stimulate impulse purchases. Furthermore, the availability of these Halāl products can interest the consumer from outside the Muslim minority.

This market for Halāl processed meats and poultry products will continue to grow in the coming months. This expansion can largely be attributed to further consumer interest in more exciting and interesting diets. This has been stimulated by increased overseas travel, a further integration into the general American population of the Muslim and other ethnic minorities, and the greater exposure of the consumer to ethnic foods, particularly Muslim foods, through larger displays at supermarkets and other groceries. By far the largest sector of the ethnic foods market is still the Italian food sector. However, Muslim food can be credited with some $3-5 \%$ of the market, slightly under the Chinese food sector. With Muslim restaurants firmly established throughout the US, the potential for the expansion of the ready meals and processed meats and poultry sector of the retail market can be substantial.

The major areas of new products activity that the Muslim consumer indentified for 1989 were microwave-specific, spice and other ethnic, sauces, Haläl processed meats and poultry products, rice and pasta products, bottled water, carbonated beverages, fiber and calcium-added products, and yogurt and yogurt-like products.

Muslim consumers are spending more on Western fast foods and less on traditional Muslim foods. This kind of expenditure is increasing because Muslim consumers have developed a taste for American-style Halal fried chicken, catfish and Halāl hamburgers.

It is increasingly obvious that Halāl is the true sophistication of the US Muslim consumer. The 1986-1988 survey indicates that fashions, unique colors, and sleek shapes, along with respected Halal brand and store names are needed to catch the eye of modern Muslim consumers.
Along with the graying of America at large, it can be estimated that within 11 years the median age of the second generation Muslim population in the US will reach 36 years, up six years $(20 \%)$ from 1980 . It is expected to be 41 years by the year $2030 .{ }^{4}$ Muslim meat processors and marketers must learn what this more mature audience will expect from processed meats and poultry and then capitalize on it.

By 1995 , more than $60 \%$ of adult Muslim women in the US will be in the work force. This will bring the time crunch. Time is becoming more valuable than money, and convenience is taking precedence over frugality; however, value still makes the sale. Hurried Muslim consumers have little tolerance for products that do not taste good or do not perform well, or for companies that do not back their products and services.

\section{Conclusion}

Muslims have adopted the US homing instinct. Muslims everywhere are retreating back into the home for relaxation, entertainment, prayers, exercise and dining. This homecoming will create new and expanded economic opportunities.

Finally, there is growing concern among young Muslims about good health. More and more American Muslims are exercising daily. These consumers want nutritious, low-chemical foods, but they want them to taste good. Even with these health conscious Muslim consumers, good tasting foods are occasionally consumed as a sort of reward for their hard work. That is why fried chicken, hamburgers, pizza and potato chips are so popular.

\section{Reference}

1. Hussain SA: An analysis of the typical diet of selected Indian/Pakistani adult Muslims in North America. JIMA 1986; 18:91.

2. Smith S: Tables of working life: The incrementdecrement model. Washington, DC: Bureau of Labor Statistics, U.S. Department of Labor, 1982.

3. Gillespie M: Association of Home Appliance Manufacturers (AHAM), Chicago, Illinois, 1989.

4. Schoen R, Woodrow K: Labor force status life tables for the United States, 1972. Demography $1980 ; 17: 297$. 